\title{
Kulturologická hledání ve středoevropském prostoru
}

\author{
Zdeňka Matyušová (České Budějovice)
}

Střední Evropa včera a dnes: proměny koncepci ll: jazyk - literatura - kultura - politika - filozofie. Kolektivní monografie. Ed. Ivo Pospíšil. Brno: Středoevropské centrum slovanských studií, 2018. 394 s. ISBN 978-8088296-01-0.

Obsáhlá kolektivní monografie s názvem Středni Evropa včera a dnes: proměny koncepci II: jazyk literatura - kultura - politika - filozofie o rozsahu téměř čtyř set stran bezprostředně navazuje na svou první část a byla vydána péčí Středoevropského centra slovanských studií, z. s., v těsné spolupráci s Ústavem slavistiky FF MU, Českou asociací slavistů a Slavistickou společností Franka Wollmana.

Tato zajímavá publikace je pestrou analýzou různých náhledů na střední Evropu a zdařilým pokusem o vystižení toho, jaká role je dnes střední Evropě přisuzována $\mathrm{v}$ celoevropském myšlení. Jak v anglicky fundovaně psané předmluvě Hledáni středni Evropy uvádí její autor Ivo Pospíšil (ČR), středoevropský prostor představuje složitý a spletitý kulturní komplex, region s pestrými a bohatými historickými a náboženskými událostmi, kolébkami revolucí a světovými válkami.

V reprezentativní knize jsou v abecedním pořádku představeny jednotlivé statě, které jsou vždy na začátku opatřené krátkou anotací a klíčovými slovy v původním jazyce článku (angličtina, čeština, polština, ruština, slovenština, ukrajinština) a abstraktem a klíčovými slovy $\mathrm{v}$ angličtině.

Předložená publikace je rozdělena na dvě stěžejní kapitoly: 1. Jazyk - literatura - kultura a 2. Historie - filozofie - kulturni historie - politika - metodologie.

V první z nich jsou otištěny následující statě: Ondřej Bláha (ČR): Strukturni rysy jazyků středni Evropy - autor hodnotí stupeň strukturních shod mezi jednotlivými jazyky střední Evropy a zamýšlí se nad historickými předpoklady konvergentního vývoje jazyků střední Evropy; Andrzej Borkowski
(Polsko): Europa Środkowa w świetle peregrynacji Jakuba Sobieskiego - o Evropě ve světle peregrace Jakuba Sobieskiho; Ivan Fedečko (ČR): Ivan Franko - proni ukrajinský Středoevropan - článek o osobnosti ukrajinského autora, překladatele a publicisty konce 19. a počátku 20. století Ivana Franka a jeho přínosu pro evropský literární proces; Marta Germušková (Slovensko): Slovenská literatura v stredoeurópskom kontexte - autorka se zaměřuje na změny $\mathrm{v}$ chápání vzájemných vztahů mezi politikou, ekonomikou, kulturou, literaturou a zajímá ji především kulturní a literární kontext a specifičnosti středoevropského kontextu; Vladimír Heger (ČR): Středni Europa slovem a obrazem v dilech W. G. Sebalda a O. Tokarczukové - jedná se o srovnávací pohled na dva romány - Austerlitz od Winfrieda Georga Sebalda (2001) a Knihy Jakubovy (2014) od Olgy Tokarczukové, které mimo jiné nastolují také otázku geografických a kulturních hranic střední Evroру; Михайло Гнатюк (Украина): Східні традихї та иентральноєвропейські орієнтири: україньска література кіния XIX - початку XX cm. - článek o orientálních tradicích, středoevropské orientaci a ukrajinské literatuře konce 19. a začátku 20. století; Zuzana Chrenková (Slovensko): Slovenská literárna moderna ako súčast’ stredoeurópskeho duchovného celku (J. C. Hronský v kontextoch a súvislostiach) - komparatistická studie je především hlubokou analýzou románu Jozefa Cígera Hronského s názvem Pisár Gráč (1940) v širším kontextu jak slovenské, tak středoevropské a evropské literární moderny; Agnieszka Janiec Nyitrai (Mad’arsko): „Nie żyć wtyranii kierunków“. Polska między Wschodem a Zachodem w eseju podrózniczym Andrzeja Stasiuka Wschód (2014) - o Polsku mezi Východem a Západem v eseji o cestování 
Andrzeje Stasiuka Východ; Мария Алексеевна Елизарьева (Россия): Центральноевропейский языковой союз - семантическая конвергениия (на примере чешского и немешкого языков) - text o jednom z nejméně prozkoumaných rysů tzv. středoevropského jazykového svazu - německého sémantického kalku v českém jazyce a některých dalších slovanských jazycích; Jana Kostincová

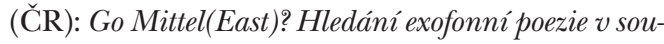
časné středni Europě - článek o současné exofonní a multilingvální poezii, poetice překladu a o současné multilingvální literární tvorbě; Petr Kučera (ČR): Šumavská literatura jako regionální literatura středoevropské periférie - o problematice německy i česky psané literární tvorby na pomezí Čech, Bavorska a Rakouska s důrazem na horskou oblast Šumavy a jejího podhůří: „Zatímco pro české autory je Šumava (a do určité míry i Pošumaví) prostorem nových objevü, pro německy pišici autory prédstavuje hranični pohoři dưvěrně známou krajinu dètství a mládí..."(s. 119); Michał Kuran (Polsko): Europa Środkowa przetomu XVI i XVII wieku - przejawy wspólnoty idei w literaturze (perspektywa polska) - o střední Evropě na přelomu 16. a 17. století - projevy společenství idejí v literatuře (polská perspektiva); Eva Kudrjavceva Malenová (ČR): Neználek Nikolaje Nosova - český fenomén ve středoeuropském kontextu - zajímavé pojednání o vydávání pohádkové trilogie o Neználkovi, jejímž autorem je ruský spisovatel pro děti a mládež Nikolaj Nosov a o výsledcích výzkumu, který potvrdil hypotézu, že v českém jazykovém kontextu vychází toto dílo $\mathrm{s}$ jistým výsadním postavením mnohem častěji než v ostatních jazykových kontextech: „Jedná se totiž o jedno z mála děl pocházejícich z ruské literatury pro děti a mládež, které vycházeji v češtině kontinuálně i po roce 1989. Zatímco současná dila ruské provenience nevycházejí v oblasti literatury pro děti a mládež vỉbec [...]. Na základě výše uvedeného lze považovat pohádky o Neználkovi za fenomén, který vévodi českým vydáním ruské literatury pro děti a mládež již po mnoho desítek let..." (s. 148-149); Martin Markoš (ČR): Nacionalismus, světoobčanství a vnimáni vlastní historie v tvorbě Jaroslava Rudiše - článek o románové, povídkové, komiksové a dramatické tvorbě autora české prózy 21. století Jaroslava Rudiše; Ivo Pospísil (ČR): Tři listy o sovětské literatuře Alfreda Ljudvigoviče Bema: ruský fenomén a středni Europa - autor pozoruhodné studie charakterizuje Alfreda Ljudvigoviče Bema jako Středoevropana, znalce ruské literatury 19. století, zakladatele pražské Společnosti Dostojevského a přináší analýzu jeho tří dopisů o sovětské literatuře z roku 1933: „Alfred Bem se zamýšlel nad osudem ruské literatury po velkém kataklyzmatu dvou revoluci roku 1917 a občanské války a obdobi rekonstrukce za Stalinozy diktatury [...] povaha nového režimu, který se začal utváret po roce 1929, zásadné ovlivnila i podobu kultury, uměni a literatury. Bem zásadni obrysy tohoto vývoje a jeho obecné rysy rystihl, tedy i to, že budoucnost ruské literatury je př́devším na územi Ruska..." (s. 172); Sergej Skorvid (Rusko): Středoevropský jazykový svaz z hlediska jeho konstituováni a konstituovanos$t i$ - příspěvek pojednává o strukturních shodách mezi slovanskými a neslovanskými jazyky ve střední Evropě, pro jejichž popis lingvisté používají termín středoevropský jazykový svaz; Jaroslav Sommer (ČR): Homosexualita jako téma pro české divadlo - článek o profesionální české divadelní scéně od roku 2010 a o inscenacích, ve kterých některá z jednajících postav vykazuje homosexuální chování; Josef Šaur (ČR): Hlavni tendence $v$ aktuálni české recepci ruské literatury - autor si všímá české recepce ruské literatury především v letech 2007-2016 na základě knižně vydaných překladů a přináší zjištění, že převážně jsou překládána díla, která přinášejí fakta o ruských dějinách 20. století a o současném Rusku; Patrik Šenkár (Slovensko): Večné a podobné zrkadlenia „rozprávkového“ sveta „stredoeurópskych" deti v intencionálnych prózach D. M. Anocovej a J. Nováka - př́spěvek je zaměřen na básnickou a prozaickou tvorbu Dagmar Márie Anocové a Jaromíra Nováka jako dvou nejvýraznějších představitelů současné slovenské literatury pro děti a mládež v Rumunsku: „Čitatel'sky expresíne je poznanie pre deti o starostiach každého cloveka na tomto svete. Dôležitý je pritom pocit patrit' $k$ niekomu... Tento svet kladie [autor - pozn. Z. M.] do kontrastu so zmeneným svetom dospelého človeka, ktorý je odlišný - až nel'udský (nenávist', zloba, egoizmus, výsmech, pohŕdanie, neochota, nepochopenie). Dôležité je teda poznat' iných l'udi i okolie a pozriet'sa do oči pria- 
mych l'udi... “ (s. 212); Tereza Šmídová (ČR): Autor a čtenár̆ v česko-slovenské fanouškovské literatuřre informace o úloze autora a čtenáře v oblasti česko-slovenské fanfiction; František Všetička (ČR): Mirákl Josefa Škvoreckého - text pojednává o výstavbě románu Mirákl (1972), který spisovatel Josef Škvorecký zpracoval na paralelním a hudebním (vesměs jazzovém) principu; Jana Waldnerová (Slovensko): Poetika humoru románu Posledni aristokratka - úvaha o románové trilogii současného českého autora Evžena Bočka s názvem Posledni aristokratka (2012); Viera Žemberová (Slovensko): Homo scribens versus homo politicus - v zajímavém textu se zdůrazňuje, že národní a geopolitické dějiny jsou provázeny osobnostmi, které svou uměleckou literaturou, kulturní publicistikou nebo eseji ve své době jako aktivně politicky se projevující jednotlivci přicházeli s názory na problémy národní a evropské.

Druhá kapitola zveřejňuje tyto př́spěvky: Iveta Bůžková (ČR): Slovinská esejistika a středni Europa - článek poukazuje na odezvu středoevropské myšlenky ve Slovinsku a zkoumá eseje Vena Taufera, Aleše Debeljaka a Draga Jančara; Oksana Blashkiv (Polsko): Dmytro Čyževs'kyj and Yurii Shevelov: Two Visions of Europe - informace o Dmitriji Čiževském a Juriji Ševelovovi a jejich dvou vizích Evropy; Alexandra Gorodecká (Č́R): Central Europe through the Eyes of a Dutchman : a Neo-colonial Depiction of Central Europe in Working with Eastern Europe (2006) by a Dutch 'Expert' on Cultural Studies Jacob Vossestein - text o střední Evropě očima Holand’ana a o holandských kulturních studiích Jacoba Vossesteina; Monika Grącka (Polsko): Rosyjska myśl narodnicka na emigracji - úvaha o ruském narodnickém myšlení v exilu; Miroslav Jeřábek (ČR): Richard Coudenhove-Kalergi a Elemér Hantos: Geopolitické a kulturni koncepty (stredni) Evropy po roce 1918 autor popisuje vlivná hnutí ve dvacátých letech 20. století vedená převážně filozofy a ekonomy; Alena Klvaňová (ČR): Fenomén nových subjekti̊ na slovinské politické scéně: problém stability stranického systému Republiky Slovinsko - příspěvek se zabývá stranickým systémem Republiky Slovinsko v posledních letech, kdy se na tamější politické scéně prezentovaly nové úspěšné poli- tické strany; Anna Kobylińska (Polsko): Niewidzialna Stowacja. Fatszywe perspektywy na ruchomej mapie Europy Środkowej - Neviditelné Slovensko. Falešné perspektivy na pohyblivé mapě střední Evropy; Michał Kopczyk (Polsko): Europa Środkowa w kontekście studiów postkolonialnych. Subiektywny raport z lektur - úvaha o střední Evropě v kontextu postkoloniálních studií; Krištof Jacek Kozak (Slovinsko): Central Europe as Cosmopolitan (Id)Entity - autor usiluje o zachycení střední Evropy jako kosmopolitní (id)entity; Маркета Поледникова (С̆R): Сдвиги в рефлексии Влади мира Соловъева в чешской и словачкой среде - роjednání je zamyšlením nad filozofickým učením ruského myslitele Vladimíra Sergejeviče Solovjova a nad posuny $\mathrm{v}$ jeho reflexi v českém a slovenském prostředí: "В области философии мы можем сегодня наблюдать тендениию направленности от практической философии к теоретической, а также можем наблюдать повышение интереса к другим дисциплинам и способам восприятия мира ( $\kappa$ теологии, эстетике, мисти ке, поэзии и т. п.). Такой подход способствует лучшему понятию философии Соловъева в челом, так как Соловъев - мыслитель всесторонний... (s. 359); Karolina Pospiszil (Polsko): Czy homo europae centralis to homo motus? Rozważania o środkowoeuropejskiej „solidarności poruszonych“ úvaha o středoevropské tzv. „solidaritě pohybu“ a odpovědi na otázku, zda je „homo europae centralis homo motus?"; Richard Změlík (ČR): Digital Humanities v literárni vědě a problematika interpretace empirických modeli - článek se zabývá problematikou Digital Humanities v literární vědě a soustředuje se především na interpretaci empirických modelů; Tereza Žáková (ČR): Co nás spojuje? Odraz česko-ukrajinských jazykových a historických interferencív současných vztazich mezi Čechy a Ukrajinci - př́ispěvek pojednává o několika stěžejních historických a jazykových interferencích, které spojují nejen český jazyk s ukrajinským jazykem, ale zejména Čechy a Ukrajince v širším slova smyslu.

Publikované literárněvědné a jazykovědné statě se ve své různorodosti odlišují jak pestrostí odborného a tematického zaměření, tak rovněž svou rozdílnou kvalitou a vypovídací hodnotou. Tato 
mnohoaspektová odborná kniha tak dává prostor pro vyjádření pluralitních názorů a úsudků z rozdîlných zorných úhlů, pro předkládání a prezentaci různorodých směrů výzkumu a bádání.

Posuzovaná multikulturní kolektivní monografie postihuje širokou paletu impulsů, které výše uvedená problematika nabízí a přispívá tak k jejímu hlubšímu pochopení a vícestrannému náhledu.

Domnívám se rovněž, že předložená publikace je podnětným příspěvkem $\mathrm{k}$ následným diskusím o výše zmíněné tematice a neměla by uniknout pozornosti zejména odborné, ale i širší veřejnosti.

\section{doc. PaedDr. Zdeňka Matyušová, Ph.D.}

Katedra slovanských jazyků a literatur

Pedagogická fakulta, Jihočeská univerzita

Jeronýmova 10, 37115 České Budějovice,Česká republika

matyus@pf.jcu.cz 